an increase in song and wading birds. Swainson hawks are increasing. Gophers are scarce, chipmunks only 2 seen, Frogs increasing, toads very scarce, muskrats increasing.

OKLA, Ross Roach

Reports a weasel working from the barn to the wood pile carrying feathers and nest material to establish a home in the wood pile. Now it is quite trme and comes within 3 feet to observe me.

WOOD RIVER

East and south of Lake Johnston, 13 painted turtles were found in a shallow pool in the wood river on October 29 th. Several were taken as nets and others transferred to deeper pools in the river.

\title{
SHARP-TAILED GROUSE
}

While travelling from Raymore to Dafoe on July 15th Mr. Alex Gee of Regina saw a weasel spring about 20 inches to the back of the bird already in flight. The weasel evidently did not secure the desired hold and at roughly $10 \mathrm{ft}$. in height the weasel fell off.

\section{ALBINO CROW --}

In July Mr. Clarence Schaefer of Kitchener, Ontario, shot an Albino crow. The bird is being prepared by Miss E. Barker, Regina, Taxidermist.

\section{PRAIRIE CHICKEN " DANCING GROUNDS"}

We are particularly intereste in hearing of remainine grouse dancing grounds. These grounds are efiected mainly through agricultural demands. Such sites are unusual and interesting enough to conserve for observation and study purposes. Information required is the land owner's name, location and dancing population.

\section{BOOKS}

"Guide to Game Birds", illustrated by Edmund J. Sawyer. This 4" $x 6 "$ 42-page pocket guide sells for $50 \phi$ and is distributed to Kee-Men, of Ducks Unlimited Canada.

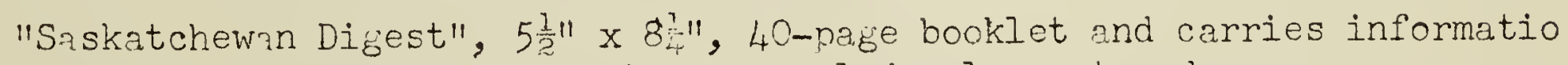
ation of occurrences in Saskatchewan, its general develonment and progress. This booklet sells for $"$ 1.00 per year and is available from the Roll Call Publications Iimited, Dominion Bank - Building, Regina, Sask.

\section{SASKATCHEWAN HISTOEIC SITES}

Through the "Blue Jay" we invite correspondence from members in every part of the province about Saskatchewan Historic Sites. While not a phase of Natural History, this subject is of real interest to everyone. who loves the great outdoors. Farly historic events are fading memories and 